\title{
Fenton-Like Oxidation of Acid Yellow 23 in the Presence of Iron Rich Soil
}

\section{Tagne Guy Merlain1, Lawrence Tatanah Nanganoa',2, Belibi Belibi Placide Desire1, Ndi Julius Nsami1 ${ }^{*}$, Ketcha Joseph Mbadcam ${ }^{1}$}

\author{
${ }^{1}$ Applied Physical and Theoretical Chemistry Laboratory, Department of Inorganic Chemistry, University of Yaoundé, \\ Yaoundé, Cameroon \\ ${ }^{2}$ Soil, Plant and Water Analysis Laboratory, Department of Soil, water and Atmosphere, Institute of Agricultural Research for \\ Development (IRAD), Buea, Cameroon \\ Email: *bigpielo2002@yahoo.com
}

How to cite this paper: Merlain, T.G., Nanganoa, L.T., Desire, B.B.P., Nsami, N.J. and Mbadcam, K.J. (2016) Fenton-Like Oxidation of Acid Yellow 23 in the Presence of Iron Rich Soil. Advances in Chemical Engineering and Science, 6, 553-569.

http://dx.doi.org/10.4236/aces.2016.65048

Received: October 14, 2016

Accepted: November 27, 2016

Published: November 30, 2016

Copyright $\odot 2016$ by authors and Scientific Research Publishing Inc. This work is licensed under the Creative Commons Attribution International License (CC BY 4.0).

http://creativecommons.org/licenses/by/4.0/

\begin{abstract}
Treatment of yellow dye 23 by heterogeneous Fenton-like process was studied using iron rich soil as an iron source. The iron rich soil sample was characterized by XRD, SEM and BET analysis. XRD pattern indicates that the iron rich soil is made of goethite and hematite. The reaction was systematically investigated under various experimental conditions such as $\mathrm{pH}$, iron rich soil dosage, oxidant and dye concentrations. The result revealed that using iron rich soil as catalyst led to high discoloration efficiency $(97.71 \%$ for $140 \mathrm{~min}$ of treatment) at $\mathrm{pH}=2.5,2 \mathrm{~g} / \mathrm{L}$ iron rich soil and 16 $\mathrm{m} \cdot \mathrm{mol} / \mathrm{L}_{2} \mathrm{O}_{2}$. The degradation kinetics of acid yellow 23 can be described by a pseudo-first-order reaction following the Langmuir-Hinshelwood mechanism. The main roles of hydroxyl radicals in degradation process were investigated by adding of various radical scavengers.
\end{abstract}

\section{Keywords}

Acid Yellow 23, Discoloration, Heterogeneous Fenton, Iron Rich Soil

\section{Introduction}

Nowadays, numbers of dyes are being widely used in textile, paper, rubber, plastic, leather, cosmetic, pharmaceutical, and food industries, which generate large volumes of wastewater every year [1]. The disposal of dye wastewater without proper treatment is a big challenge as it causes drastic threat to the aquatic environment owing to their bioresistance, visibility, toxicity and carcinogenic effects [2] [3]. Some of the dyes present in wastewater even decompose into carcinogenic aromatic amines under anaerobic conditions and cause serious health problems to human beings as well as other animals 
[4]. Therefore, an effective and economic treatment of effluents containing diverse dyes has become a necessity for clean production technology for industries [5]. Several methods exist for the treatment of colored wastewater. These include: adsorption, coagulation and flocculation, biological treatment, photo catalytic process, advanced oxidation processes etc [6]. In recent years, advanced oxidation processes (AOPs) become important technologies for water treatment [7] [8] and, have received considerable attention for the destructive oxidation of dyes, since many aromatic compounds have proven to be degraded effectively to $\mathrm{CO}_{2}, \mathrm{H}_{2} \mathrm{O}$, and small molecules [9]. The Fenton oxidation process is one of the AOPs which involve the catalytic oxidation of organics in waste water using hydroxyl radicals generated from the reaction between the iron (II) cations and hydrogen peroxide $\left(\mathrm{H}_{2} \mathrm{O}_{2}\right)$. The advantage of the Fenton oxidation process over other AOPs is that it is economical, convenient to use, produces non-toxic by-products and does not require any sophisticated or expensive instruments [10]. Despite its strong oxidation capacity, homogeneous Fenton or Fenton-like reaction operation has some critical limitations such as a narrow $\mathrm{pH}$ range, post-treatment requirements prior to discharge as a result of iron hydroxide sludge formation, and unattainable regeneration of catalyst which hampers the economic feasibility of this process [11]. To overcome these drawbacks, some efforts have been made to develop different heterogeneous (photo-) Fenton-like catalysts including the incorporation of iron ions or iron oxides within the structure of catalyst support [12] [13] [14]. Most of the iron sources studied includes synthesized iron oxide such as $\left(\mathrm{Fe}_{3} \mathrm{O}_{4}\right)$, hematite $\left(\alpha-\mathrm{Fe}_{2} \mathrm{O}_{3}\right)$, maghemite $\left(\gamma-\mathrm{Fe}_{2} \mathrm{O}_{3}\right)$ and goethite $(\alpha-\mathrm{FeOOH})$ [15]. However, to the best of our knowledge, little attention has been paid to the catalytic property of iron rich soils. In comparison with other solid catalysts such as natural clays, resin supports and zeolites, iron rich soil possesses higher content in Fe (II) ions. In fact, due to the lack of iron in the composition of the aforementioned catalysts, sophisticated methods such as impregnation, hydrothermal and ion exchange are employed to achieve suitable percentage of $\mathrm{Fe}$ (II) ions in the final catalysts [16] [17] [18]. In this study, we used iron rich soil as a catalyst for the discoloration of Tartrazine (Acid Yellow23, trisodium1-(4-sulfonatophenyl)-4-(4-sulfonatophenylazo)-5-pyrazolone-3 carboxylate) Tartrazine is a orangecolored, water soluble powder widely used in food products, drugs, cosmetics and pharmaceuticals. The estimated amounts of tartrazine manufactured in 1996 were approximately 71.35 metric tons in Japan and 985.76 metric tons in USA [19] experimental results suggest that it might adversely affect human health [20]. The influence of several parameters such as solution $\mathrm{pH}$, the $\mathrm{H}_{2} \mathrm{O}_{2}$ amount, catalyst amount, initial dye concentration, and inorganic salts on the heterogeneous Fenton-like oxidation of acid yellow 23 using iron rich soil were investigate. Also, the pseudo-first order rate constant $\left(k_{\text {app }}\right)$ was calculated by a kinetic model (based on non-linear regression analysis) as a function of initial Acid Yellow 23 concentration.

\section{Experimental Study}

\subsection{Materials}

The acid yellow 23 dye and the hydrogen peroxide solution (50\% in mass) were pur- 
chased from Merck (Germany) and used without any purification. The absorption spectra of acid yellow are characterized by two main bands, one in the visible region $(\lambda$ $\max =420 \mathrm{~nm}$ ) which is responsible for the chromophoric components. In this study, the decay in the band at $420 \mathrm{~nm}$ was investigated as a function of time as a measure of the discoloration degree. All aqueous solutions were prepared with distilled water.

\subsection{Characterization of Natural Iron Oxide}

To determine the mineralogical phases of the iron rich soil sample, XRD characterization was carried out at room temperature using a Shimadzu 6000 spectrometer operating on a $\mathrm{Cu}-\mathrm{K} \alpha$ radiation. The surface morphology and the structure of the iron rich soil were obtained using a scanning electron microscopy (SEM) (FEIQuanta 250 FEG $\mathrm{SEM})$ ) at an acceleration voltage of $10 \mathrm{kV}$. Nitrogen sorption analyses were obtained with a sorptometer (Micrometrics, ASAP-2010). The surface area was calculated according to the BET method.

\subsection{Sorption Experiments}

All equilibrium sorption experiments were conducted at $\mathrm{pH}=2.5$. The iron rich samples were mixed with variable concentrations of acid yellow 23. The equilibrium of Acid Yellow 23 adsorption was achieved within 40 minutes. After equilibrium, the samples were filtered and analyzed by UV-visible spectroscopy and adsorbed amount of the dye were calculated according to Equation (1).

$$
Q_{e}=\left(\frac{C_{o}-C_{e}}{m}\right) \times V
$$

where,

$Q_{e}(\mathrm{mg} / \mathrm{g})$ is the sorption capacity at equilibrium, $C_{o}(\mathrm{mg} / \mathrm{L})$ is the initial and $C_{e}$ $(\mathrm{mg} / \mathrm{L})$ is the acid yellow 23 concentration at equilibrium. $V(\mathrm{~L})$ is the volume of solution, $m(\mathrm{~g})$ is the mass of iron rich soil. The effect of $\mathrm{pH}$ on adsorption of acid yellow 23 on iron rich soil were performed with a single initial dye concentration in a $20 \mathrm{~mL}$ closed reaction vessel at a constant temperature. The $\mathrm{pH}$ was controlled by adding aliquots $0.1 \mathrm{M}$ of $\mathrm{HCl}$ or $\mathrm{NaOH}$ to the stock solid suspensions. The Acid Yellow 23 residual concentration in solution was determined by measuring its absorbance using a UV-Vis spectrophotometer (PerkinElmer), with a $1 \mathrm{~cm}$ quartz cell.

\subsection{Discoloration of Azo-Dye Acid Yellow}

The experiments were carried out in a conical flask (containing $100 \mathrm{~mL}$ of reaction solution). The dosage of catalyst was $1.0-3.0 \mathrm{~g} \cdot \mathrm{L}^{-1}$ while the concentrations of Acid yellow and $\mathrm{H}_{2} \mathrm{O}_{2}$ were $20-50 \mathrm{~m} \cdot \mathrm{mol} \cdot \mathrm{L}^{-1}$ and $4-24 \mathrm{~m} \cdot \mathrm{mol} \cdot \mathrm{L}^{-1}$, respectively. All the experiments were carried out under constant stirring. The $\mathrm{pH}$ of solution was adjusted by $0.1 \mathrm{M} \mathrm{H}_{2} \mathrm{SO}_{4}$ and $\mathrm{NaOH}$. Before degradation reaction, the suspension containing catalyst and Acid Orange II was stirred for $40 \mathrm{~min}$ to achieve adsorption equilibrium. Then the degradation reaction was initiated by adding $\mathrm{H}_{2} \mathrm{O}_{2}$ in the Acid yellow solution. Then the degradation reaction was initiated by adding $\mathrm{H}_{2} \mathrm{O}_{2}$ into Acid yellow solution. 
Equation (2) was used to find the discoloration efficiency $(D E(\%))$

$$
D E(\%)=\frac{\left(C_{o}-C_{t}\right)}{C_{o}} \times 100
$$

where, $C_{o}(\mathrm{mg} / \mathrm{L})$ is the initial concentration of Acid yellow 23 and $C_{t}(\mathrm{mg} / \mathrm{L})$ is the concentration of acid yellow 23 at reaction $t(\mathrm{~min})$.

\section{Results and Discussion}

\subsection{Characterization of Catalysts}

Figure 1 shows the XRD peaks of the iron rich soil, the peaks at d-spacing of $1.70 \mathrm{~A}^{\circ}$; $2.71 \AA$; $2.52 \AA$; $2.21 \AA ; 1.84 \AA$; $1.70 \AA$ are associated with hematite phase according to the standard powder diffraction data (JCPDS). Also, the XRD peaks at $\mathrm{d}$ of 4.20 , and 2, $51 \AA$ are related to the goethite phase. In addition, a broad band between 05 and $20^{\circ}$ observed in the XRD patterns indicates the presence of amorphous materials. So the existence of goethite $(\mathrm{FeO}(\mathrm{OH}))$ and hematite $\left(\mathrm{Fe}_{2} \mathrm{O}_{3}\right)$, proved that the iron rich soil contains iron oxides and oxyhydroxides

Scanning electron microscopy (SEM) coupled with energy dispersive spectroscopy (EDS) that provides a qualitative elemental analysis of the material are presented on Figure 2. On the SEM micrograph, particles observed are spherical and of irregular shape. Energy dispersive X-ray elemental analysis depicts a composition characteristic of iron oxide/oxyhydroxide. The elemental composition that is presented in Figure 2 is closed to goethite composition (ideally, iron content in goethite is $63 \%$ and here the analysis indicates about $55 \%$ iron).

The surface area, pore diameter, and pore volume of soil sample were characterized by $\mathrm{N}_{2}$ adsorption-desorption. The $\mathrm{N}_{2}$ adsorption-desorption isotherms and pore size distribution curves of iron rich soil are shown in Figure 3. The shape of the isotherms seems to be nearly type IV isotherm according to the IUPAC classification. The shape of the hysteresis loops is of type $\mathrm{H}_{3}$, indicating narrow slit-shaped pores that is generally

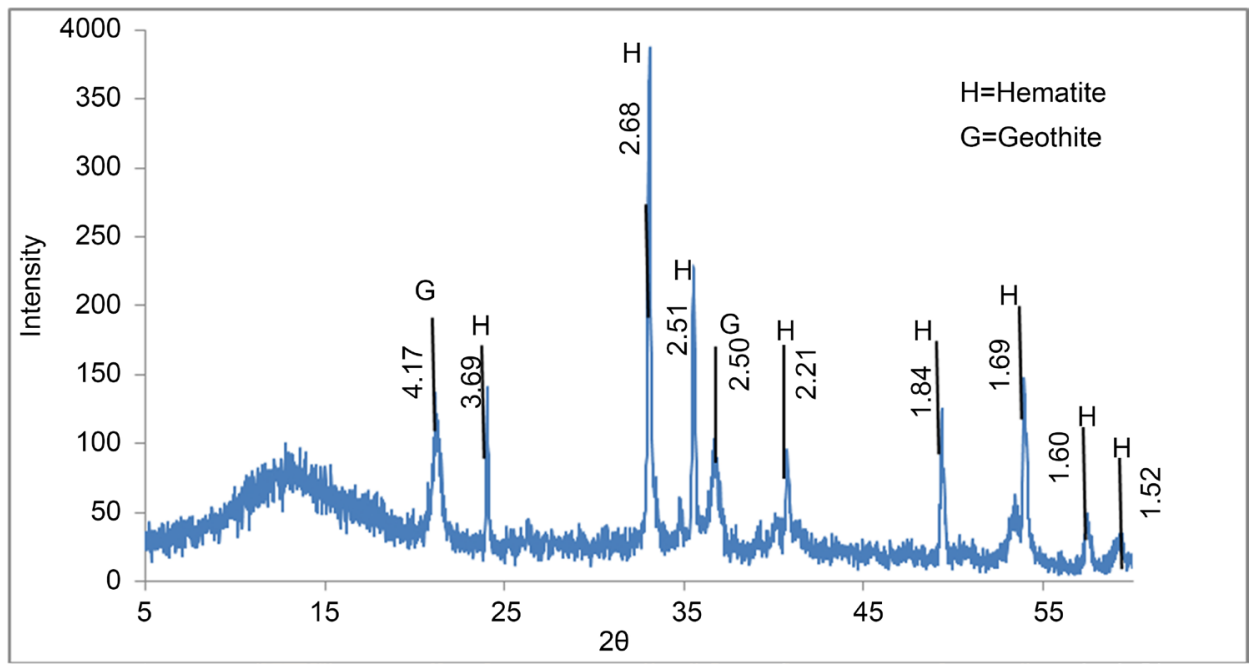

Figure 1. XRD spectra of natural iron rich soil used in this study. 

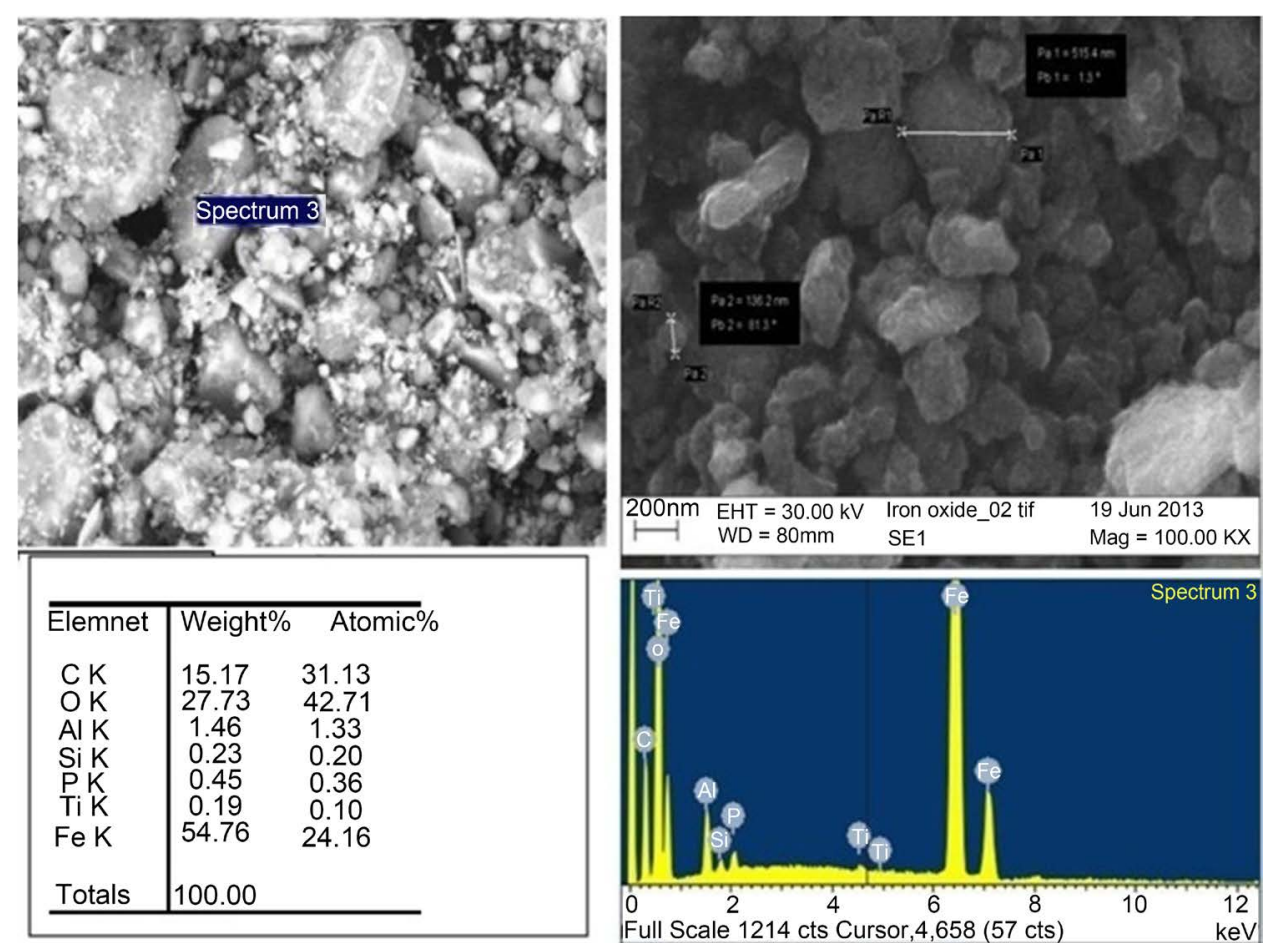

Figure 2. Scanning electron microscopy (SEM) coupled with energy dispersive spectroscopy (EDS) patterns for iron rich soil.

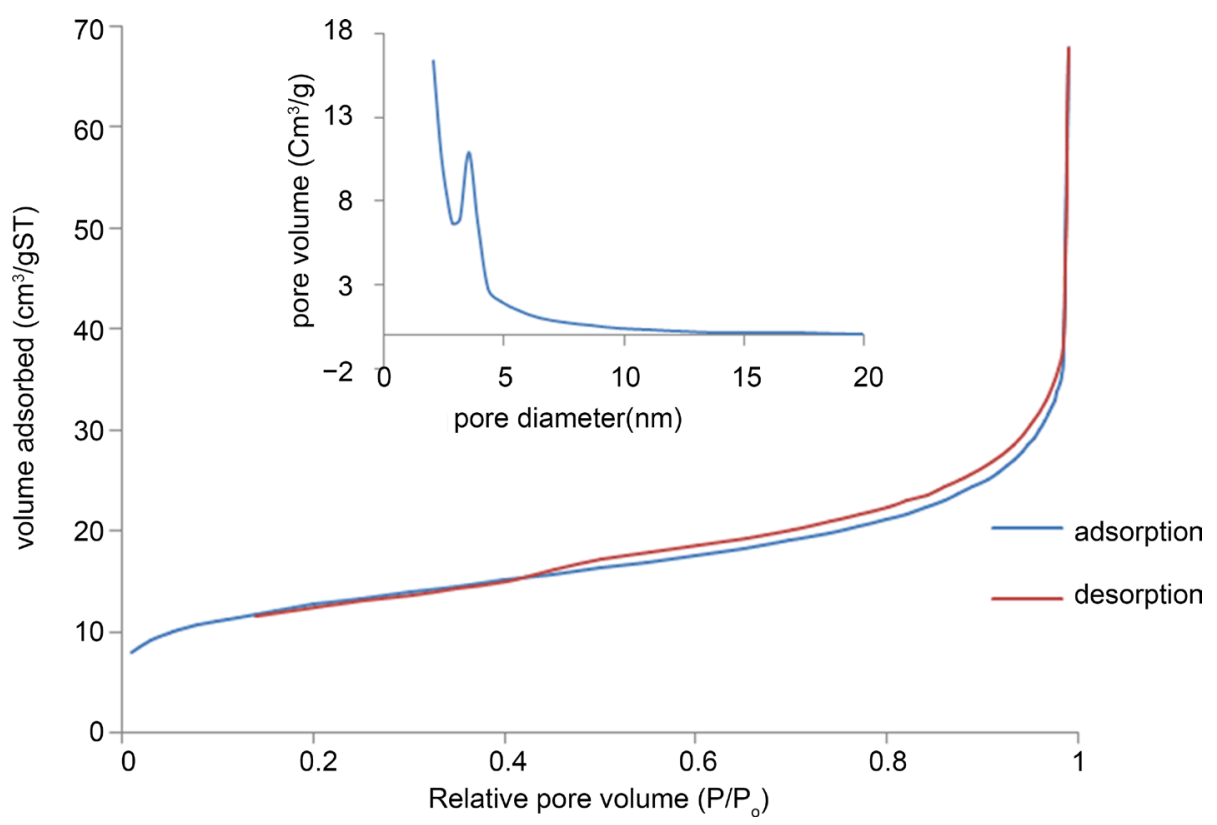

Figure 3. Adsorption-desorption isotherm of $\mathrm{N}_{2}$. The inset shows pore size distribution of iron rich soil sample.

associated with plate-like particles [21].

The BET surface area, total pore volume and average pore size of the iron rich soil are summarized in Table 1. 
Table 1. Physicochemical properties of iron rich soil.

\begin{tabular}{cccc}
\hline $\begin{array}{c}\mathrm{S}_{\mathrm{BET}} \\
\left(\mathrm{m}^{2} / \mathrm{g}\right)\end{array}$ & $\begin{array}{c}\text { Average pore size } \\
(\mathrm{nm})\end{array}$ & Total pore volume $\left(\mathrm{cm}^{3} / \mathrm{g}\right)$ & PZC \\
\hline 42.26 & $12.36 \mathrm{~nm}$ & 0.089 & 4.2 \\
\hline
\end{tabular}

\subsection{Adsorption of Acid Yellow on Natural Iron Oxide}

Adsorption Isotherms were determined to assess acid yellow distribution between solid and aqueous phases (Figure 4).

The experimental isotherm data were fitted to the Langmuir and Freundlich equations, applying linear regression analysis. The best fit was observed with the Langmuir model. The linear form of the Langmuir equation is given by Equation (3).

$$
\frac{C_{e}}{Q_{e}}=\frac{C_{e}}{Q_{m}}+\frac{1}{K Q_{m}}
$$

where, $C_{e}$ is the equilibrium concentration $\left(\mathrm{mg} \cdot \mathrm{L}^{-1}\right), Q_{e}$ is the amount of adsorbate adsorbed per unit mass of the adsorbent at equilibrium $(\mathrm{mg} / \mathrm{g}), k$ is the Langmuir adsorption constant $\left(\mathrm{L} \cdot \mathrm{mg}^{-1}\right)$ and $Q_{m}$ is the maximum amount of acid yellow 23 adsorb per unit mass of adsorbent to form a complete monolayer on the surface $(\mathrm{mg} / \mathrm{g})$. The Langmuir isotherm constants obtained by plotting $C_{e} / Q_{e}$ versus $C_{e}$ are $Q_{m}=6.329$ $\mathrm{mg} / \mathrm{g}$ and $K_{L}=0.313 \mathrm{~L} \cdot \mathrm{mg}^{-1}$.

\subsection{Effect of pH Dose on Discoloration Rate of Acid Yellow}

The influence of initial $\mathrm{pH}$ of the dye solution on the discoloration of acid yellow efficiency was studied using five solutions with initial $\mathrm{pH}$ of 2.0, 2.5, 3.0, 3.5 and 4.0 and without any modifications or control of $\mathrm{pH}$ during the process. Figure 5 shows the discoloration of dye as a function of the initial $\mathrm{pH}$ of the solution at various reaction times.

The obtained results indicated that the discoloration of acid yellow 23 was significantly influenced by the solution $\mathrm{pH}$. The increase of the initial $\mathrm{pH}$ led to a much lower degradation rate. It has been confirmed that low $\mathrm{pH}$ promotes the stability of hydrogen peroxide and slowed its decomposition [22] [23]. Therefore, the decrease of $\mathrm{pH}$ would slow the decomposition of $\mathrm{H}_{2} \mathrm{O}_{2}$, which may slow the discoloration process. However, in this study the decrease of initial $\mathrm{pH}$ has led to a much larger degradation rate. This can be attributed to two aspects: Firstly, possible leaching of Fe from the catalyst at $\mathrm{pH}$ slightly acid contributing to homogeneous Fenton reaction. Secondly, the electrostatic interactions between the acid yellow 23 molecules and the iron rich soil surface at $\mathrm{pH}$ [24]. Iron concentration in reaction solutions were measured at $\mathrm{pH} 2.5$ and 3.0 and the value were $4.58 \mathrm{mg} / \mathrm{L}$ and $1.15 \mathrm{mg} / \mathrm{L}$ respectively. This can justify why the discoloration efficiency at $\mathrm{pH} 2.5$ is higher than the discoloration at $\mathrm{pH}$ 3.0.

In order to verify the second hypothesis, the sorption of acid yellow 23 on the iron rich soil was investigated by varying the $\mathrm{pH}$ from 2 to 10 , using the same experimental conditions as for the oxidation. The results (Figure 6), showed that the adsorption quantity decrease when the $\mathrm{pH}$ increase. This imply that the electrostatic interactions 


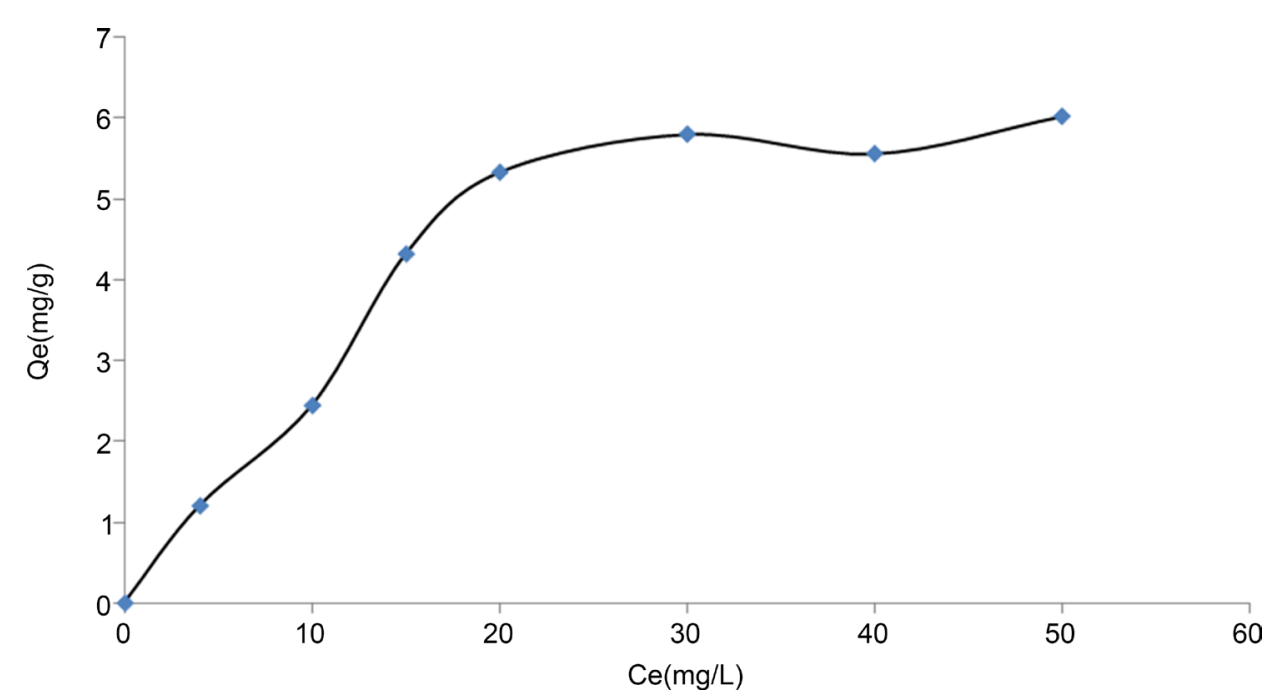

Figure 4. Adsorption isotherm of yellow dye onto iron rich soil.

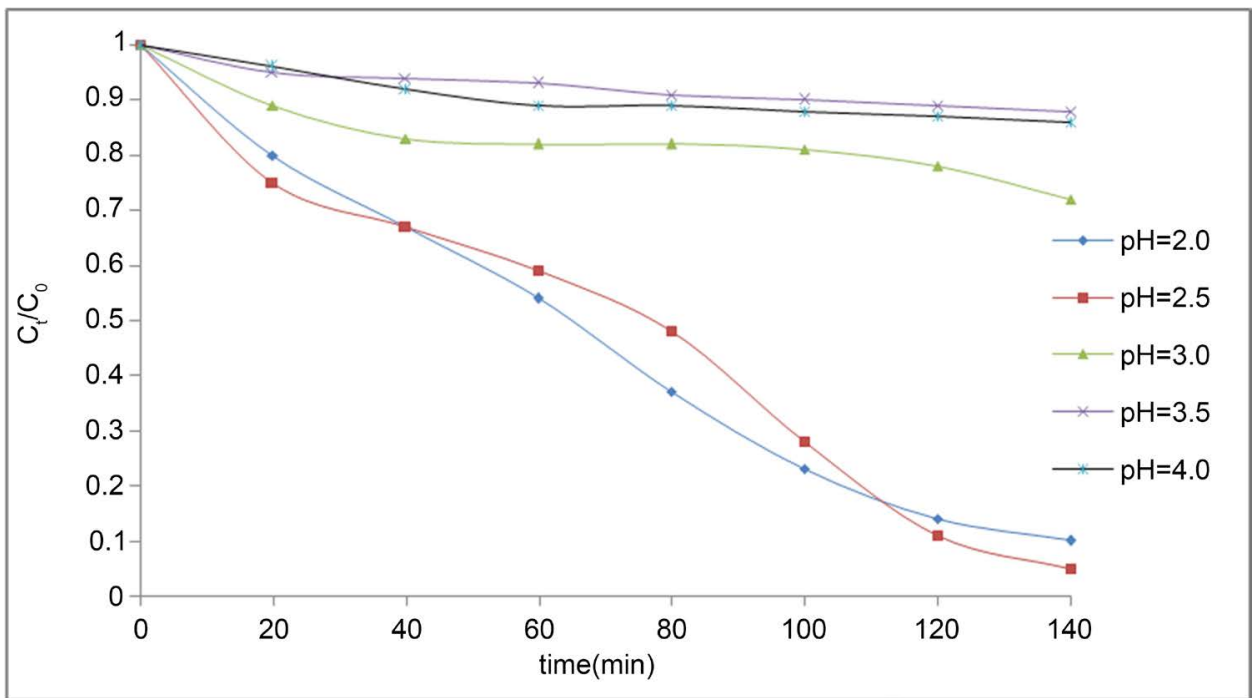

Figure 5. Effect of $\mathrm{pH}$ on the discoloration efficiency of acid yellow. Experimental conditions: [acid yellow 23] $=30 \mathrm{mg} \cdot \mathrm{L}^{-1},\left[\mathrm{H}_{2} \mathrm{O}_{2}\right]=16 \mathrm{mM}$, iron rich soil $=2.50 \mathrm{~g} \cdot \mathrm{L}^{-1}$.

between partial negative charges on the acid yellow 23 molecule and the positive $\mathrm{Fe}-\mathrm{OH}_{2}{ }^{+}$surface groups on iron rich soil that increased as $\mathrm{pH}$ decreased [25] (PZC > 4.2 , Table 1) favorite the discoloration of acid yellow 23. Consequently, both the amount of iron leaching and the surface reaction contributed to the discoloration of acid yellow 23 [26].

\subsection{Effect of Hydrogen Peroxide Concentration}

The effect of $\mathrm{H}_{2} \mathrm{O}_{2}$ concentration was investigated in the range of 4 to $24 \mathrm{~m} \cdot \mathrm{mol} \cdot \mathrm{L}^{-1}$. The results obtained are presented graphically in Figure 7. When the concentration of $\mathrm{H}_{2} \mathrm{O}_{2}$ was $4 \mathrm{mmol} \cdot \mathrm{L}^{-1}$, the discoloration process was slow due to the insufficient ${ }^{\circ} \mathrm{OH}$ in aqueous solution. As the concentration of $\mathrm{H}_{2} \mathrm{O}_{2}$ increased to $24 \mathrm{~m} \cdot \mathrm{mol} \cdot \mathrm{L}^{-1}$, the process 


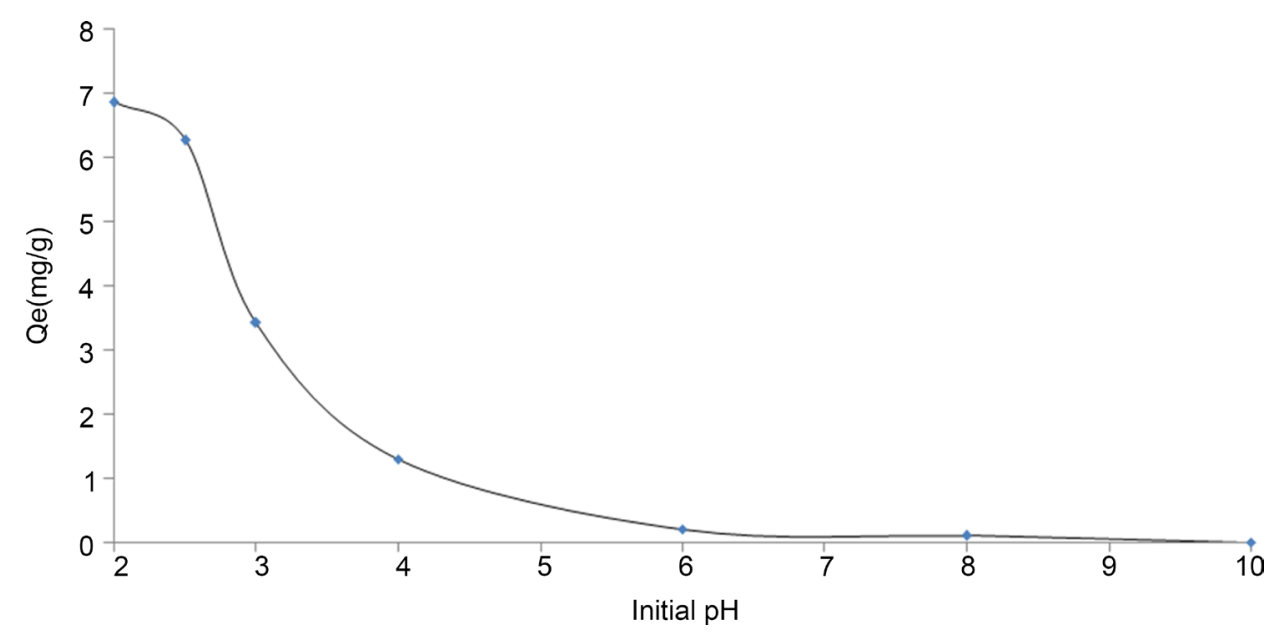

Figure 6. Effect of initial $\mathrm{pH}$ on the adsorption acid yellow. Experimental conditions: [acid yellow 23] $=30 \mathrm{mg} \cdot \mathrm{L}^{-1}$, iron rich soil $=2.50 \mathrm{~g} \cdot \mathrm{L}^{-1}$.

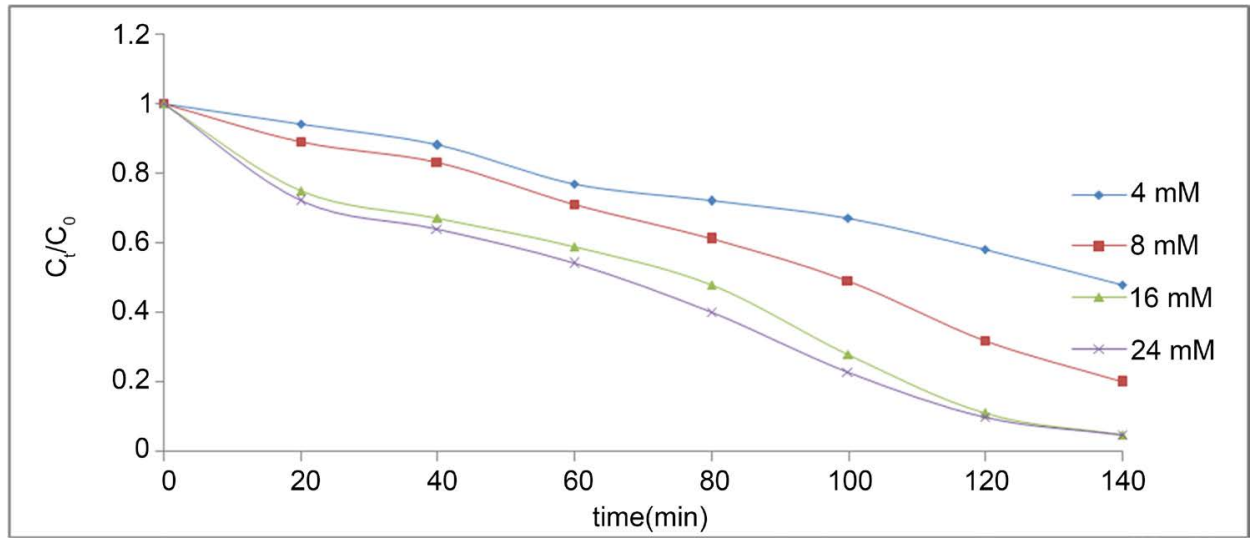

Figure 7. Effect of hydrogen peroxide concentration on the discoloration efficiency of acid yellow. Experimental conditions: [acid yellow 23] $=30 \mathrm{mg} \cdot \mathrm{L}^{-1}, \mathrm{pH}=2.5$, Iron rich soil $=2.50 \mathrm{~g} \cdot \mathrm{L}^{-1}$.

was significantly accelerated, because more radicals were formed.

\subsection{Effect of Iron Rich Soil Dosage on the Discoloration of Acid Yellow 23}

The effect of iron rich soil dosage on the discoloration of acid yellow 23 was investigated in the presence of different amounts of iron rich soil in solution $(1,1.5,2,2.5$ and $\left.3.0 \mathrm{~g} \cdot \mathrm{L}^{-1}\right)$, the results are depicted in Figure 8. The results indicate that when the amount of iron rich soil in solution increases from 1.0 to $2.0 \mathrm{~g} / \mathrm{L}$, the discoloration efficiency also increases from $25.12 \%$ to $97.74 \%$. This can be ascribed to two causes; it provides additional surface area for adsorption and also additional amount of Fe for the formation of $\mathrm{OH}$ radicals. Further increase in the iron rich soil amount slightly decreases the discoloration efficiency, which could be ascribed to the inhibition effect caused by excess iron ions in the heterogeneous Fenton process that act as scavengers as shown by Equation (4) [26]. 


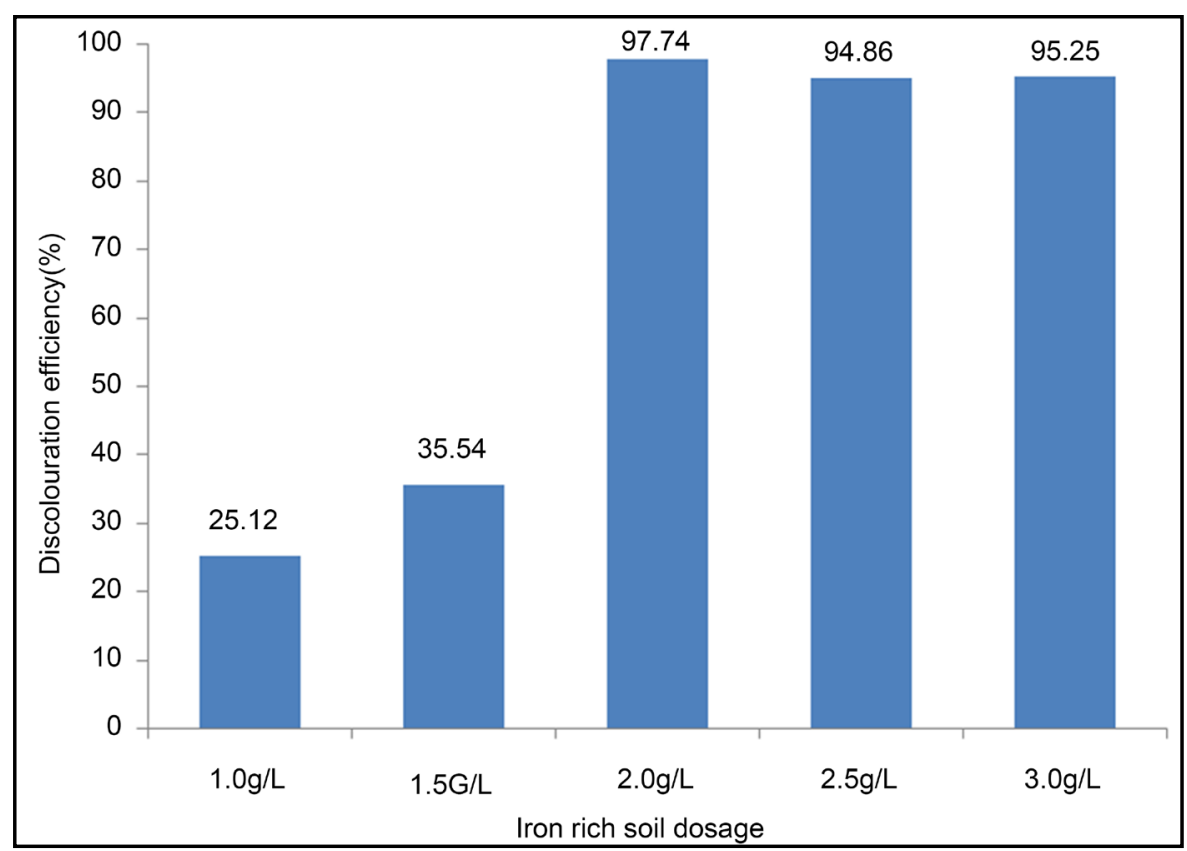

Figure 8. Effect of Iron rich soil dosage on the discoloration efficiency of acid yellow 23. Experimental conditions: [acid yellow 23] $=30 \mathrm{mg} \cdot \mathrm{L}^{-1},\left[\mathrm{H}_{2} \mathrm{O}_{2}\right]=16 \mathrm{mM}, \mathrm{pH}=2.5$.

$$
\mathrm{Fe}^{2+}+{ }^{\cdot} \mathrm{OH} \longrightarrow \mathrm{Fe}^{3+}+\mathrm{OH}^{-}
$$

\subsection{Influence of Initial Concentration of Acid Yellow 23 on Discoloration}

Previous studies have shown that the effectiveness of Fenton process for the degradation of organic compounds depends on the initial concentration of the pollutant For example, S. Karthikeyan et al. 2013 [9], have shown during the treatment of synthetic phenol solution by Fenton-like process using natural Fe-Co-Al trimetal oxide (TMO) as a heterogeneous catalyst that the process was more effective for diluted solutions more than for concentrated ones. It can be seen in Figure 9(a) that by increasing the concentration of Acid yellow from 20 to $50 \mathrm{mg} \mathrm{L}^{-1}$, the removal of acid yellow 23 decreased from $98.71 \%$ to $65.06 \%$ during $140 \mathrm{~min}$ of the reaction. There are two main reasons for explained the behavior. First, by raising the concentration of acid yellow 23, high amount of acid yellow 23 molecules would adsorb on the surface of iron rich soil. In this way, more and more hydroxyl radical $(\mathrm{OH})$ for treatment of solution are needed. In other words, the amount of reactive radicals is not enough to oxidize the excessive concentration of Acid yellow due to constant rate of hydroxyl radical formation on the iron rich soil for various concentrations of acid yellow. Second, increasing the concentration of Acid yellow 23 leads to formation of various degradation intermediates or byproducts that may adsorb on the iron rich soil surface and deactivate the active sites of the iron rich soil. Consequently, the removal efficiency plunges as the concentration increases [27] [28] [29].

In order to obtain the kinetic information, the experimental results were fit with a 
pseudo-first-order Equation (5).

$$
\ln \left(\frac{C_{t}}{C_{o}}\right)=k_{\text {app }} t
$$

where, $C_{\mathrm{o}}(\mathrm{mg} / \mathrm{L})$ is the initial concentration of Acid yellow 23 and $C_{\mathrm{t}}(\mathrm{mg} / \mathrm{L})$ is the concentration of acid yellow 23 at reaction $\mathrm{t}(\mathrm{min})$ and $K_{\text {app }}$ reaction rate of the pseudo-first-order kinetic model.

As it can be seen in Figure 9(b), the reaction rate of the pseudo-first-order kinetic model $\left(k_{\text {app }}\right)$ is decreased from 0.02 to $0.01 \mathrm{~min}^{-1}$ with increasing initial acid yellow concentration from 20 to $50 \mathrm{mg} \cdot \mathrm{L}^{-1}$. The heterogeneous reaction of the degradation of organics encompasses with both oxidation and adsorption that occurs simultaneously [30], and can be described by the Langmuir Hinshelwood mechanism [31] [32], which can be expressed as follows:

$$
\begin{aligned}
K_{\text {app }} & =\frac{K_{s} \times K_{r}}{1+K_{r} \times[\text { Dye }]} \\
\frac{1}{K_{\text {app }}} & =\frac{[D y e]}{K_{r}}+\frac{1}{K_{s} \times K_{r}}
\end{aligned}
$$

where,

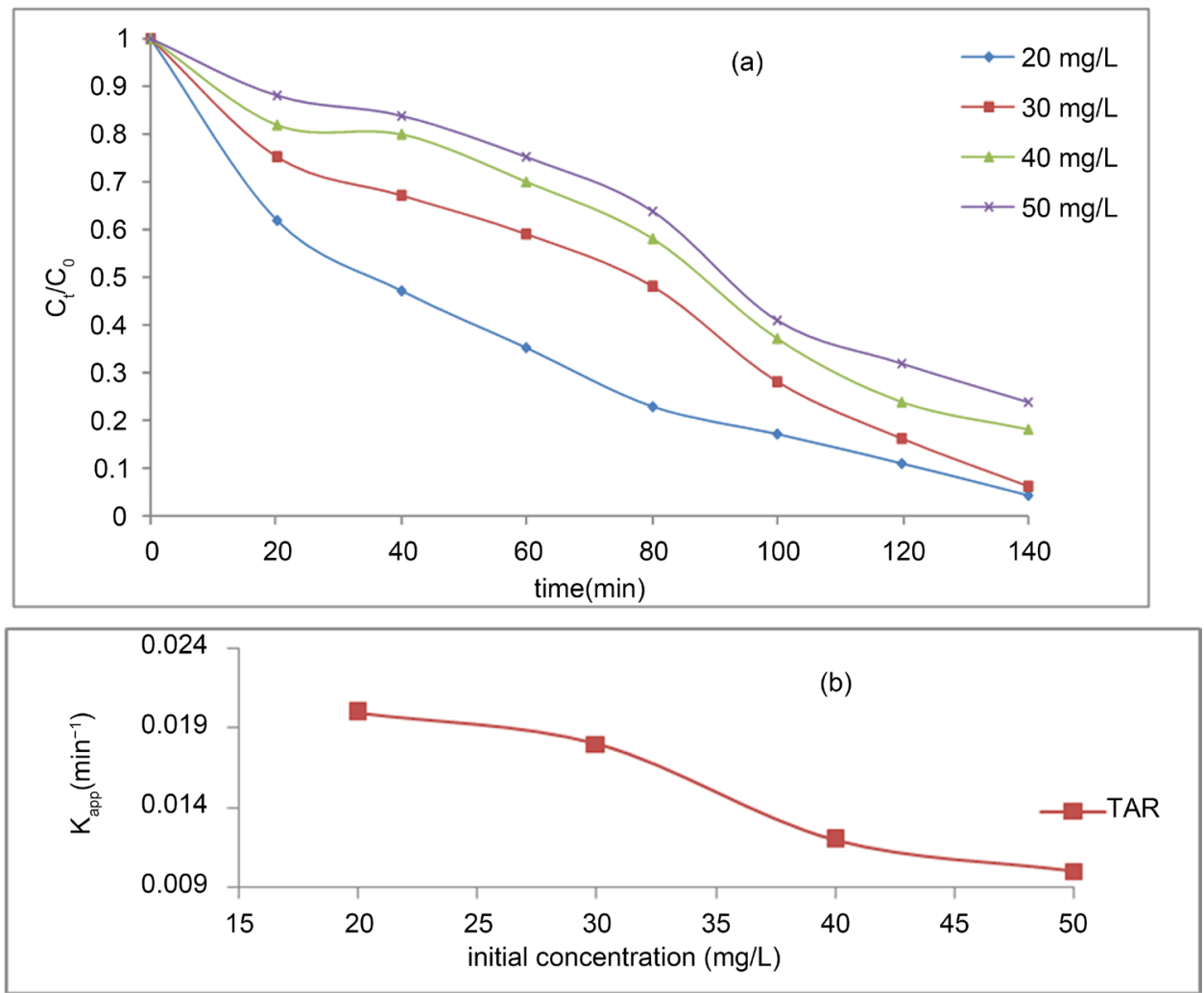

Figure 9. (a) Effect of acid yellow concentration on the discoloration efficiency of acid yellow. Experimental conditions: $\left[\mathrm{H}_{2} \mathrm{O}_{2}\right]=16 \mathrm{mM}, \mathrm{pH}=2.5$ Iron rich soil $=2.50 \mathrm{~g} \cdot \mathrm{L}^{-1}$. (b) Variation of apparent kinetic constant at different acid yellow concentrations. 
$K_{s}$ is the intrinsic surface reaction rate constant $\left(\mathrm{mg} \cdot \mathrm{L}^{-1} \cdot \mathrm{min}^{-1}\right)$ and $K_{r}$ is the Langmuir-Hinshelwood adsorption equilibrium constant $\left(\mathrm{L} \cdot \mathrm{mg}^{-1}\right)$. The values of $K_{s}$ and $K_{r}$ can be calculated by plotting the $\left(1 / K_{\mathrm{app}}\right)$ against [Dye]. As can be seen in Figure 10, the experimental data fits reasonably well $\left(R^{2}=0.98\right)$ with the proposed Langmuir-Hinshelwood mechanism. Hence, the catalytic surface reactions between the iron rich soil active sites, acid yellow 23 and $\cdot \mathrm{OH}$ radicals can be used in determining the kinetics of the heterogeneous reaction.

The $K_{s}$ and $K_{r}$ values were obtained as $0.579 \mathrm{mg} \cdot \mathrm{L}^{-1} \cdot \mathrm{min}^{-1}$ and $0.132 \mathrm{~L} \cdot \mathrm{mg}^{-1}$, respectively. The $K_{r}$ value was found to be lower than the sorption constant $\left(K_{L}=0.313\right.$ $\mathrm{L} \cdot \mathrm{mg}^{-1}$ ) in absence of an oxidant according to the Langmuir adsorption model as shown in Figure 5 indicating the existence of competitive adsorption between acid yellow 23 and $\mathrm{H}_{2} \mathrm{O}_{2}$ towards the active sites during the reaction [33].

\subsection{Spectral Changes of Acid Yellow 23 during Discoloration Process}

The changes in the absorption spectra of acid yellow solution during the discoloration process at different reaction times are shown in Figure 11. It appears from the spectra that, before the treatment, the UV-Vis spectrum of acid yellow 23 is characterized by one main band at $420 \mathrm{~nm}$ in the visible region. This band is related to the color of acid yellow solution ( $\mathrm{n} \rightarrow \pi^{*}$ transition in $\mathrm{N}=\mathrm{N}$ group). Upon treatment it is observed that the adsorption band decreased gradually, indicating that the $\mathrm{N}=\mathrm{N}$ bond and the conjugated $\pi^{*}$ system were completely destroyed [34].

\subsection{Effect of Hydroxyl Radical Scavengers on the Discoloration of Acid Yellow 23}

Chloride, sulfate and nitrate are regular inorganic anions in industrial effluents and may influence the treatment efficiency, which is called the salting-out effect. Figure 12 indicates that the presence of these chemicals in the dye solutions decline the acid

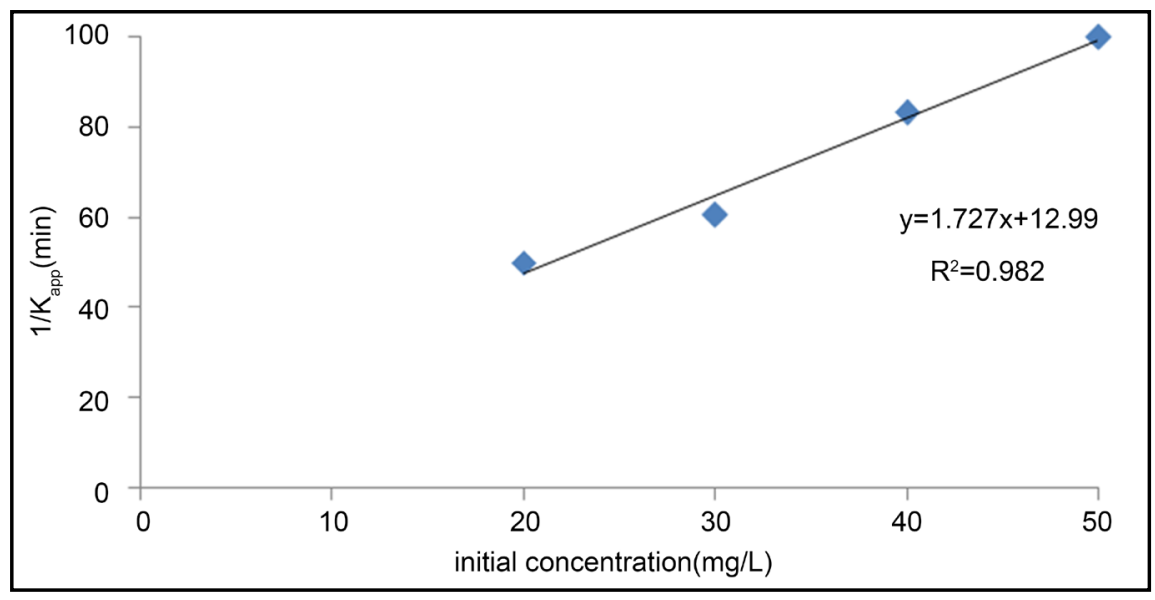

Figure 10. Determination of the adsorption equilibrium constant, $K_{s}$, and the second order rate constant, $K_{r}$, for the Langmuir-Hinshelwood model. Experimental conditions: $\left[\mathrm{H}_{2} \mathrm{O}_{2}\right]=16 \mathrm{mM}$, $\mathrm{pH}=2.5$ iron rich soil $=2.5 \mathrm{~g} \cdot \mathrm{L}^{-1}$. 


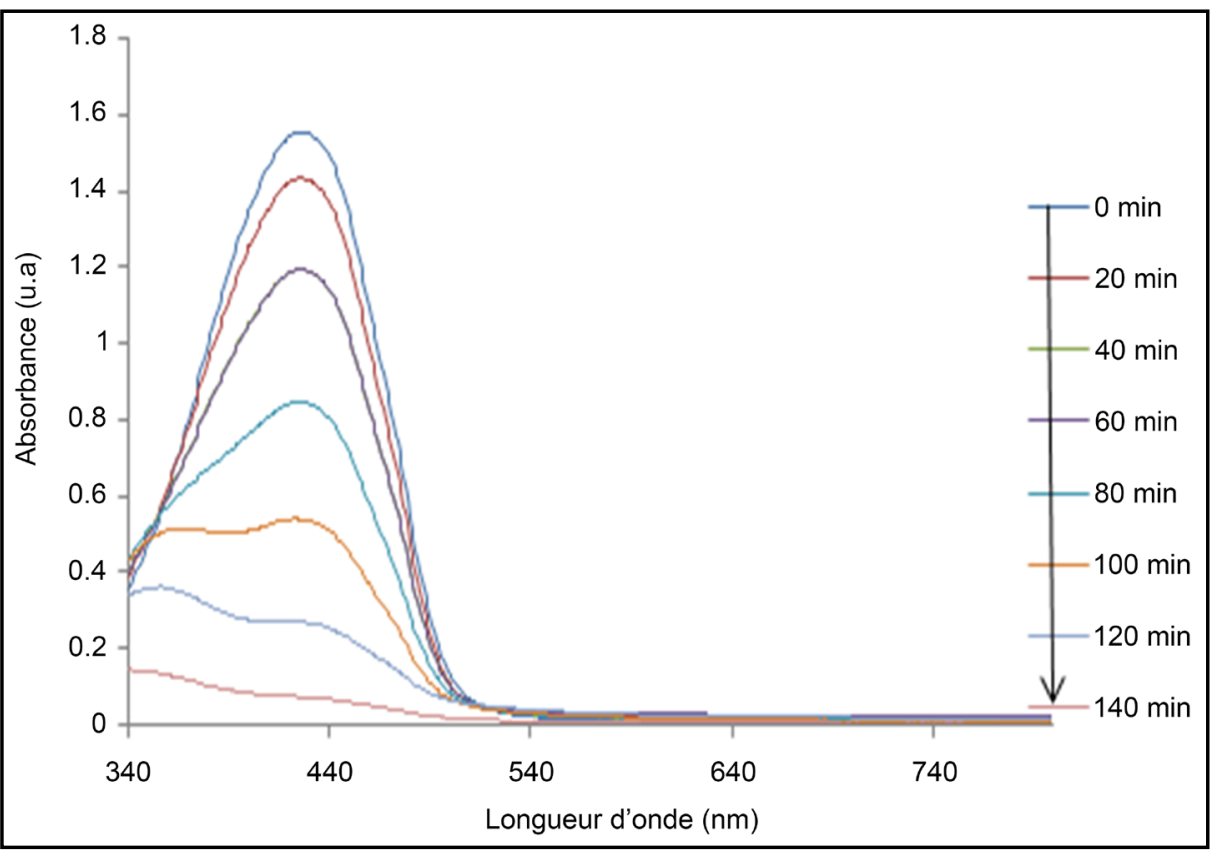

Figure 11. UV-Vis spectral changes of acid yellow. Experimental conditions: [acid yellow 23] = $30 \mathrm{mg} \cdot \mathrm{L}^{-1},\left[\mathrm{H}_{2} \mathrm{O}_{2}\right]=16 \mathrm{mM}, \mathrm{pH} 2.5$ iron rich soil $=2 \mathrm{~g} \cdot \mathrm{L}^{-1}$.

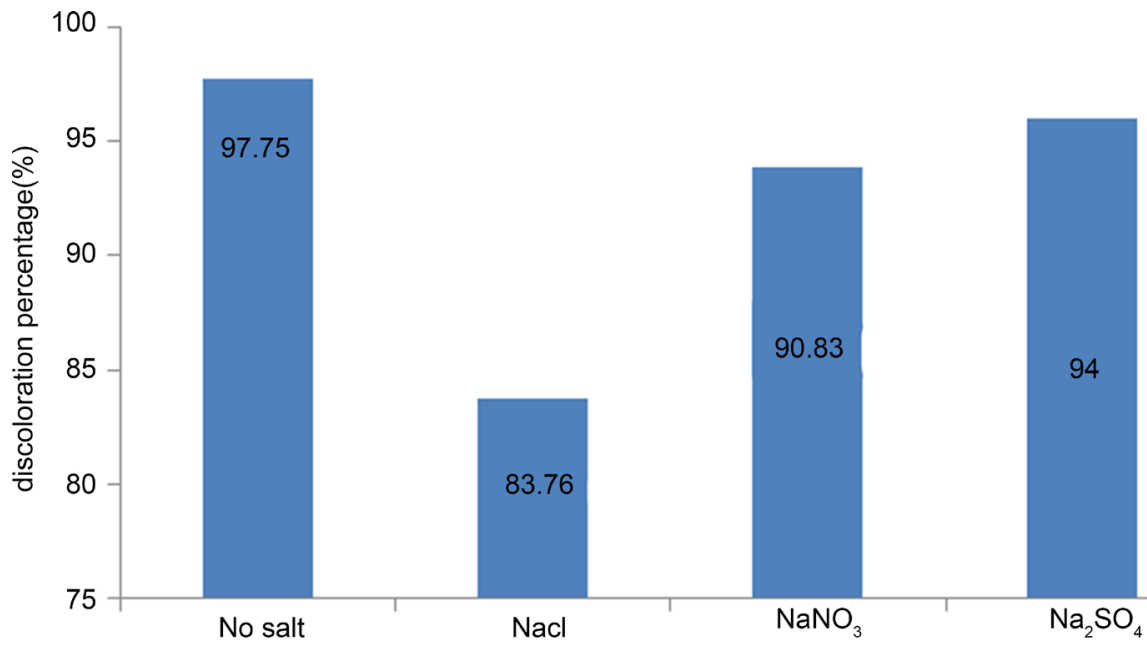

Figure 12. Effect of inorganic salts on the discoloration of acid yellow. Experimental conditions: [acid yellow 23] $=30 \mathrm{mg} \cdot \mathrm{L}^{-1},\left[\mathrm{H}_{2} \mathrm{O}_{2}\right]=16 \mathrm{mM}, \mathrm{pH} 2.5$ iron rich soil $=2 \mathrm{~g} \cdot \mathrm{L}^{-1} \cdot[\mathrm{salt}]=1 \mathrm{~g} / \mathrm{L}$.

yellow 23 discoloration efficiency. The degradation rates was highly affected in the presence of chlorides, this may be due to several factors: 1) the decrease in $\mathrm{H}_{2} \mathrm{O}_{2}$ decomposition rate and so decrease in hydroxyl radical generation rate, 2) the decrease in acid adsorption rate because of the competition with $\mathrm{Cl}^{-}$or 3) the scavenging of - $\mathrm{OH}$ by chloride and the formation of reactive radicals with low oxidation potential rather than ${ }^{-} \mathrm{OH}$ by the Equations (8)-(10) [35] [36]: Furthermore, the generated ${ }^{\circ} \mathrm{Cl}$ radicals have a great tendency to react with $\mathrm{H}_{2} \mathrm{O}_{2}$, which declines ${ }^{\circ} \mathrm{OH}$ formation (Equation (11)) [37]. 


$$
\begin{gathered}
\mathrm{Cl}^{-}+{ }^{\cdot} \mathrm{OH} \longrightarrow \mathrm{ClOH}^{\cdot-} \\
\mathrm{ClOH}^{\cdot-}+\mathrm{H}^{+} \longrightarrow \mathrm{Cl}^{\cdot}+\mathrm{H}_{2} \mathrm{O} \\
\mathrm{Cl}^{-}+\mathrm{Cl}^{\cdot} \longrightarrow \mathrm{Cl}_{2}^{-} \\
\mathrm{Cl}^{\cdot}+\mathrm{H}_{2} \mathrm{O}_{2} \longrightarrow \mathrm{HO}_{2} \cdot \mathrm{Cl}^{-}+\mathrm{H}^{+}
\end{gathered}
$$

Moreover, Sulfate ions and nitrate ions can also react with ${ }^{\circ} \mathrm{OH}$ and lead to the formation of $\mathrm{SO}_{4}{ }^{--}$and $\mathrm{NO}_{3}{ }^{\cdot}$ radicals respectively with low oxidation potential (Equation (12) Equation (13)) [38] [39]. This decreases the acid yellow 23 discoloration efficiency

$$
\begin{aligned}
& \mathrm{NO}_{3}^{-}+{ }^{\cdot} \mathrm{OH} \longrightarrow \mathrm{NO}_{3}{ }^{\cdot}+\mathrm{OH} \\
& \mathrm{SO}_{4}^{2-}+{ }^{\cdot} \mathrm{OH} \longrightarrow \mathrm{SO}_{4}^{\cdot-}+\mathrm{OH}^{-}
\end{aligned}
$$

\subsection{Application to Real Water Sample}

The efficiency of iron rich soil as catalyst for the discoloration of acid yellow in real water was investigated. A sample of river water was collected and was spiked with 30 $\mathrm{mg} / \mathrm{L}$ of acid yellow. Some of the characteristic of the river water are DCO $=125 \mathrm{mg} / \mathrm{L}$, $\mathrm{pH}=4.4$. The discoloration procedure was the same as the one described in the section 2.3It appears that the discoloration percentage of acid yellow decreases from $97.75 \%$ to $75.73 \%$ respectively for distilled water and for river water for identical operating conditions. This decrease can be explained by the scavenging effect of salt present in the river water.

\subsection{Stability of the Catalyst}

The stability of the catalysts under the $\mathrm{H}_{2} \mathrm{O}_{2}$ is a crucial point for the application of Fenton's systems in oxidation processes. The data presented in Figure 13 showed the stability and activity of iron rich soil in recycling tests. After each operation cycle, the

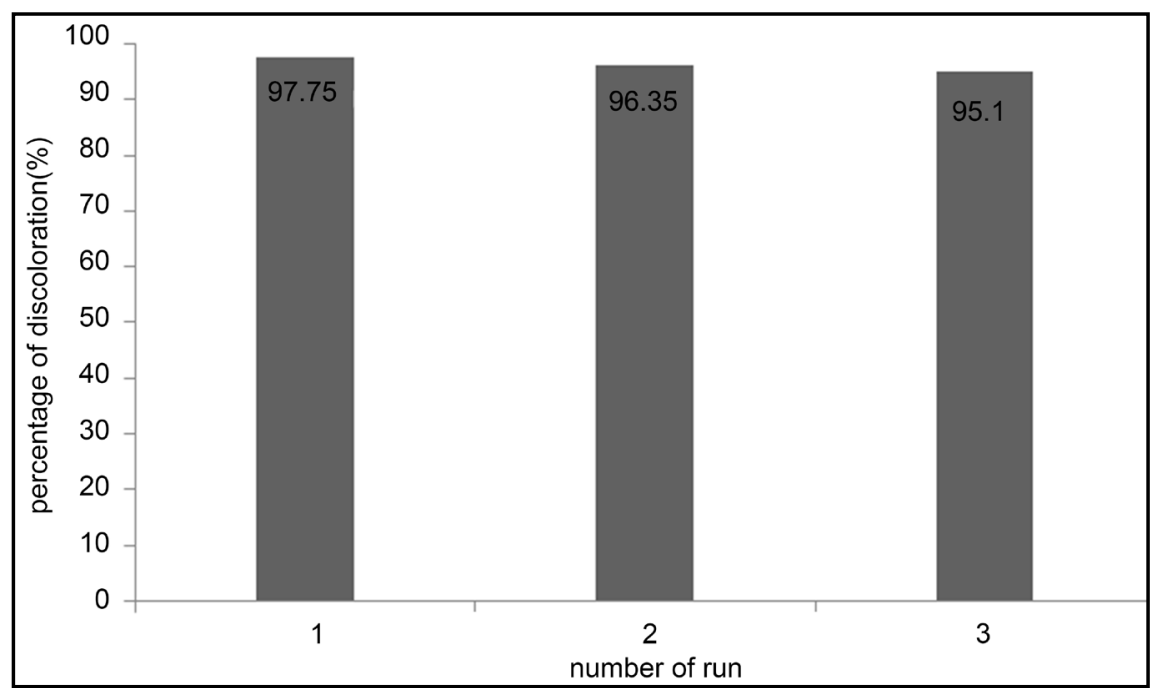

Figure 13. Discoloration efficiencies for three successive run. Experimental conditions: [Acid yellow 23] $=30 \mathrm{mg} / \mathrm{L},\left[\mathrm{H}_{2} \mathrm{O}_{2}\right]=16 \mathrm{mM}, \mathrm{pH}=2.5$ and Iron rich soil $=2 \mathrm{~g} \cdot \mathrm{L}^{-1}$. 
catalyst was separated, washed with $\mathrm{H}_{2} \mathrm{O}$ and used in the next run. The discoloration of acid yellow after $140 \mathrm{~min}$ in the 3 cycles considered were $97.75 \%, 96.35 \%$ and $95.10 \%$, respectively. The slight activity decay observed may be due to the Fe leaching from iron rich soil. This behavior shows that Iron rich soil can be utilized as a promising and stable catalyst in heterogeneous Fenton process for the degradation of organic pollutants with great reusability potential.

\section{Conclusion}

In this study, the heterogeneous Fenton-like oxidation of acid yellow dye was investigated in the presence of an iron-rich soil catalyst. The iron-rich soil catalyst acted as an efficient and stable catalyst for this process. $97 \%$ discoloration yield was achieved after 140 minutes of reaction with $16 \mathrm{mM} \mathrm{H}_{2} \mathrm{O}_{2}, 2.5 \mathrm{~g} / \mathrm{L}$ of iron rich soil at $\mathrm{pH}=2.5$ for 30 $\mathrm{g} / \mathrm{L}$ acid yellow 23 dye solution. Both homogeneous and heterogeneous reactions contribute to the degradation process. The heterogeneous Fenton-like discoloration of acid yellow followed the pseudo-first order kinetics and explained in terms of the Langmuir-Hinshelwood kinetic model. Iron rich soil exhibits stable performance after three cycles. In all of the experiments, concentration of the iron leaching was below to the standard of Environmental Quality (Sewage and Industrial Effluents) Regulation 1979 $\left(<5 \mathrm{mg} / \mathrm{dm}^{3}\right)$.

\section{Acknowledgements}

The authors gratefully acknowledge Dr. Issac NONGWE BEAS, Department of Civil and Chemical Engineering UNISA, RSA for recording the BET of the samples and also to Dr. TIYA Antoine for recording the XRD of the samples.

\section{References}

[1] Hu, Z., Chen, H., Ji, F. and Yuan, S. (2010) Removal of Congo Red from Aqueous Solution by Cattail Root. Journal of Hazardous Materials, 173, 292-297. https://doi.org/10.1016/j.jhazmat.2009.08.082

[2] Noroozi, B., Sorial, G., Bahrami, H. and Arami, M. (2007) Equilibrium and Kinetic Adsorption Study of a Cationic Dye by a Natural Adsorbent-Silkworm pupa. Journal of Hazardous Materials, 139, 167-174. https://doi.org/10.1016/j.jhazmat.2006.06.021

[3] García-Montaño, J., Torrades, F., Pérez-Estrada, L.A., Oller, I., Malato, S., Maldonado, M.I. and Peral, J. (2008) Degradation Pathways of the Commercial Reactive Azo Dye Procion Red H-E7B under Solar-Assisted Photo-Fenton Reaction. Environmental Science \& Technology, 42, 6663-6670. https://doi.org/10.1021/es800536d

[4] Chen, K.C., Wu, J.Y., Yang, W.B. and Hwang, S.C.J. (2003) Evaluation of Effective Diffusion Coefficient and Intrinsic Kinetic Parameters on Azo Dye Biodegradation Using PVAImmobilized Cell Beads. Biotechnology and Bioengineering, 83, 821-832. https://doi.org/10.1002/bit.10730

[5] Romero, A., Santos, A. and Vicente, F. (2009) Chemical Oxidation of 2, 4-Dimethylphenol in Soil by Heterogeneous Fenton Process. Journal of Hazardous Materials, 162, 785-790. https://doi.org/10.1016/j.jhazmat.2008.05.123

[6] Nanganoa, L., Ketcha, J. and Ndi, J. (2014) Kinetic and Equilibrium Modeling of the Ad- 
sorption of Amaranth from Aqueous Solution onto Smectite Clay. Research Journal of Chemical Sciences, 4, 7-14.

[7] Oliveira, L., Gonçalves, M., Guerreiro, M., Ramalho, T., Fabris, J., Pereira, M. and Sapag, K. (2007) A New Catalyst Material Based on Niobia/Iron Oxide Composite on the Oxidation of Organic Contaminants in Water via Heterogeneous Fenton Mechanisms. Applied Catalysis A: General, 316, 117-124. https://doi.org/10.1016/j.apcata.2006.09.027

[8] Wang, S. (2008) A Comparative Study of Fenton and Fenton-Like Reaction Kinetics in Decolourisation of Wastewater. Dyes and Pigments, 76, 714-720.

https://doi.org/10.1016/j.dyepig.2007.01.012

[9] Karthikeyan, S., Boopathy, R., Gupta, V. and Sekaran, G. (2013) Preparation, Characterizations and Its Application of Heterogeneous Fenton Catalyst for the Treatment of Synthetic Phenol Solution. Journal of Molecular Liquids, 177, 402-408.

https://doi.org/10.1016/j.molliq.2012.10.011

[10] Chen, Y., Wang, K. and Lou, L. (2004) Photodegradation of Dye Pollutants on Silica Gel Supported $\mathrm{TiO}_{2}$ Particles under Visible Light Irradiation. Journal of Photochemistry and Photobiology A: Chemistry, 163, 281-287. https://doi.org/10.1016/j.jphotochem.2003.12.012

[11] Karthikeyan, S., Gupta, V., Boopathy, R., Titus, A. and Sekaran, G. (2012) A New Approach for the Degradation of High Concentration of Aromatic Amine by Heterocatalytic Fenton Oxidation: Kinetic and Spectroscopic Studies. Journal of Molecular Liquids, 173, 153-163. https://doi.org/10.1016/j.molliq.2012.06.022

[12] Zhang, G., Wang, S. and Yang, F. (2012) Efficient Adsorption and Combined Heterogeneous/Homogeneous Fenton Oxidation of Amaranth Using Supported Nano-FeOOH as Cathodic Catalysts. The Journal of Physical Chemistry C, 116, 3623-3634. https://doi.org/10.1016/j.cej.2013.06.020

[13] Gan, P.P. and Li, S.F.Y. (2013) Efficient Removal of Rhodamine B Using a Rice Hull-Based Silica Supported Iron Catalyst by Fenton-Like Process. Chemical Engineering Journal, 229, 351-363. https://doi.org/10.1080/19443994.2015.1044915

[14] Ünnü, B.A., Gündüz, G. and Dükkanc1, M. (2016) Heterogeneous Fenton-Like Oxidation of Crystal Violet Using an Iron Loaded ZSM-5 Zeolite. Desalination and Water Treatment, 57, 11835-11849. https://doi.org/10.1016/j.apcatb.2012.02.026

[15] Pinto, I.S., Pacheco, P.H., Coelho, J.V., Lorencon, E., Ardisson, J.D., Fabris, J.D., de Souza, P.P., Krambrock, K.W., Oliveira, L.C. and Pereira, M.C. (2012) Nanostructured $\delta$-FeOOH: An Efficient Fenton-Like Catalyst for the Oxidation of Organics in Water. Applied Catalysis B: Environmental, 119, 175-182. https://doi.org/10.1016/j.apcatb.2006.08.012

[16] Ramirez, J.H., Costa, C.A., Madeira, L.M., Mata, G., Vicente, M.A., Rojas-Cervantes, M.L., López-Peinado, A.J. and Martín-Aranda, R.M. (2007) Fenton-Like Oxidation of Orange II Solutions Using Heterogeneous Catalysts Based on Saponite Clay. Applied Catalysis B: Environmental, 71, 44-56. https://doi.org/10.1016/j.apcatb.2010.07.006

[17] Navalon, S., Alvaro, M. and Garcia, H. (2010) Heterogeneous Fenton Catalysts Based on Clays, Silicas and Zeolites. Applied Catalysis B: Environmental, 99, 1-26. https://doi.org/10.1016/j.chemosphere.2004.09.080

[18] Liou, R.-M., Chen, S.-H., Hung, M.-Y., Hsu, C.-S. and Lai, J.-Y. (2005) Fe (III) Supported on Resin as Effective Catalyst for the Heterogeneous Oxidation of Phenol in Aqueous Solution. Chemosphere, 59, 117-125.

[19] Ishimitsu, S., Mishima, I., Tsuji, S. and Shibata, T. (1998) Comparison of Estimated Production of Coal-Tar Dyes in Japan and USA. Food Sanitation and Research, 48, 33-40. 
[20] Tanaka, T., Takahashi, O., Oishi, S. and Ogata, A. (2008) Effects of Tartrazine on Exploratory Behavior in a Three-Generation Toxicity Study in Mice. Reproductive Toxicology, 26, 156-163. https://doi.org/10.1016/j.reprotox.2008.07.001

[21] Liu, S. and Yu, J. (2008) Cooperative Self-Construction and Enhanced Optical Absorption of Nanoplates-Assembled Hierarchical $\mathrm{Bi}_{2} \mathrm{WO}_{6}$ Flowers. Journal of Solid State Chemistry, 181, 1048-1055. https://doi.org/10.1016/j.jssc.2008.01.049

[22] Watts, R.J., Foget, M.K., Kong, S.-H. and Teel, A.L. (1999) Hydrogen Peroxide Decomposition in Model Subsurface Systems. Journal of Hazardous Materials, 69, 229-243. https://doi.org/10.1016/S0304-3894(99)00114-4

[23] Li, G., Qu, J., Zhang, X., Liu, H. and Liu., H. (2006) Electrochemically Assisted Photocatalytic Degradation of Orange II: Influence of Initial pH Values. Journal of Molecular Catalysis A: Chemical, 259, 238-244. https://doi.org/10.1016/j.molcata.2006.06.038

[24] Andreozzi, R., D’Apuzzo, A. and Marotta, R. (2002) Oxidation of Aromatic Substrates in Water/Goethite Slurry by Means of Hydrogen Peroxide. Water Research, 36, 4691-4698. https://doi.org/10.1016/S0043-1354(02)00204-X

[25] Andreozzi, R., Caprio, V. and Marotta, R. (2002) Oxidation of 3, 4-Dihydroxybenzoic Acid by Means of Hydrogen Peroxide in Aqueous Goethite Slurry. Water Research, 36, 27612768. https://doi.org/10.1016/S0043-1354(01)00499-7

[26] Guo, S., Zhang, G. and Wang, J. (2014) Photo-Fenton Degradation of Rhodamine B Using $\mathrm{Fe}_{2} \mathrm{O}_{3}$-Kaolin as Heterogeneous Catalyst: Characterization, Process Optimization and Mechanism. Journal of Colloid and Interface Science, 433, 1-8. https:/doi.org/10.1016/j.jcis.2014.07.017

[27] Tekbaş, M., Yatmaz, H.C. and Bektaş, N. (2008) Heterogeneous Photo-Fenton Oxidation of Reactive Azo Dye Solutions Using Iron Exchanged Zeolite as a Catalyst. Microporous and Mesoporous Materials, 115, 594-602. https:/doi.org/10.1016/j.micromeso.2008.03.001

[28] Neamtu, M., Zaharia, C., Catrinescu, C., Yediler, A., Macoveanu, M. and Kettrup, A. (2004) Fe-Exchanged Y Zeolite as Catalyst for Wet Peroxide Oxidation of Reactive Azo Dye Procion Marine H-EXL. Applied Catalysis B: Environmental, 48, 287-294.

https:/doi.org/10.1016/j.apcatb.2003.11.005

[29] Khataee, A., Khataee, A., Fathinia, M., Hanifehpour, Y. and Joo, S.W. (2013) Kinetics and Mechanism of Enhanced Photocatalytic Activity under Visible Light Using Synthesized $\operatorname{Pr}_{x} \mathrm{Cd}_{1-x}$ Se Nanoparticles. Industrial \& Engineering Chemistry Research, 52, 13357-13369. https:/doi.org/10.1021/ie402352g

[30] Xue, X., Hanna, K., Abdelmoula, M. and Deng, N. (2009) Adsorption and Oxidation of PCP on the Surface of Magnetite: Kinetic Experiments and Spectroscopic Investigations. Applied Catalysis B: Environmental, 89, 432-440. https:/doi.org/10.1016/j.apcatb.2008.12.024

[31] Xu, W., Kong, J.S., Yeh, Y.-T.E. and Chen, P. (2008) Single-Molecule Nanocatalysis Reveals Heterogeneous Reaction Pathways and Catalytic Dynamics. Nature Materials, 7, 992-996. https:/doi.org/10.1038/nmat2319

[32] Daneshvar, N., Rasoulifard, M., Khataee, A. and Hosseinzadeh, F. (2007) Removal of C.I. Acid Orange 7 from Aqueous Solution by UV Irradiation in the Presence of ZnO Nanopowder. Journal of Hazardous Materials, 143, 95-101. https:/doi.org/10.1016/j.jhazmat.2006.08.072

[33] Zubir, N.A., Yacou, C., Zhang, X. and Da-Costa, J.C.D. (2014) Optimisation of Graphene Oxide-Iron Oxide Nanocomposite in Heterogeneous Fenton-Like Oxidation of Acid Orange 7. Journal of Environmental Chemical Engineering, 2, 1881-1888. 
https:/doi.org/10.1016/j.jece.2014.08.001

[34] Deng, J., Jiang, J., Zhang, Y., Lin, X., Du, C. and Xiong, Y. (2008) $\mathrm{FeVO}_{4}$ as a Highly Active Heterogeneous Fenton-Like Catalyst towards the Degradation of Orange II. Applied Catalysis B: Environmental, 84, 468-473. https:/doi.org/10.1016/j.apcatb.2008.04.029

[35] Kwon, B.G., Lee, D.S., Kang, N. and Yoon, J. (1999) Characteristics of p-Chlorophenol Oxidation by Fenton's Reagent. Water Research, 33, 2110-2118.

https:/doi.org/10.1016/S0043-1354(98)00428-X

[36] Khataee, A., Sheydaei, M., Hassani, A., Taseidifar, M. and Karaca, S. (2015) Sonocatalytic Removal of an Organic Dye Using $\mathrm{TiO}_{2} /$ Montmorillonite Nanocomposite. Ultrasonics Sonochemistry, 22, 404-411. https:/doi.org/10.1016/j.ultsonch.2014.07.002

[37] Ortega-Liébana, M., Sánchez-López, E., Hidalgo-Carrillo, J., Marinas, A., Marinas, J. and Urbano, F. (2012) A Comparative Study of Photocatalytic Degradation of 3-Chloropyridine under UV and Solar Light by Homogeneous (Photo-Fenton) and Heterogeneous $\left(\mathrm{TiO}_{2}\right)$ Photocatalysis. Applied Catalysis B: Environmental, 127, 316-322.

https:/doi.org/10.1016/j.apcatb.2012.08.036

[38] Soltani, R.D.C., Rezaee, A., Khataee, A. and Safari, M. (2014) Photocatalytic Process by Immobilized Carbon Black/ZnO Nanocomposite for Dye Removal from Aqueous Medium: Optimization by Response Surface Methodology. Journal of Industrial and Engineering Chemistry, 20, 1861-1868. https:/doi.org/10.1016/j.jiec.2013.09.003

[39] Deng, C., Hu, H., Ge, X., Han, C., Zhao, D. and Shao, G. (2011) One-Pot Sonochemical Fabrication of Hierarchical Hollow CuO Submicrospheres. Ultrasonics Sonochemistry, 18, 932-937. https:/doi.org/10.1016/j.ultsonch.2011.01.007

Submit or recommend next manuscript to SCIRP and we will provide best service for you:

Accepting pre-submission inquiries through Email, Facebook, LinkedIn, Twitter, etc. A wide selection of journals (inclusive of 9 subjects, more than 200 journals)

Providing 24-hour high-quality service

User-friendly online submission system

Fair and swift peer-review system

Efficient typesetting and proofreading procedure

Display of the result of downloads and visits, as well as the number of cited articles

Maximum dissemination of your research work

Submit your manuscript at: http://papersubmission.scirp.org/

Or contact aces@scirp.org 